\title{
Cognitive functions and anti-oxidant in children with sickle cell disease: A single center based study
}

\author{
Niveen Salama ${ }^{1,2^{*}}$, Reham Fahmy ${ }^{3,4}$ and Eman R. Youness $5^{5,6}$
}

\section{Introduction}

Sickle cell disease (SCD) is an inherited disorder that causes many harmful pathological effects. Patients with SCD were found to exhibit a state of chronic oxidative stress with a higher potential for oxidative damage due to increased resting oxygen consumption and circulating pro-oxidative free hemoglobin [1]. Further sources of oxidants which are unique to SCD vasculature include xanthine oxidase, nitric oxide and secondary oxides of nitrogen [2]. Previous studies had shown correlation between markers of oxidative stress and common secondary diseases in SCD, such as acute chest syndrome and pulmonary hypertension [3]. Other disease related complications include infections, neurological, cardiac manifestations, and cognitive deficits [4].

Vitamins and trace minerals are known key buffers against oxidative damage. Chronic increase in the oxidative stress results in overuse of oxidative buffering capacity and may produce conditional deficiencies in key amino acids and enzymatic cofactors [5]. There are several published series demonstrating reduced levels of antioxidant vitamins, enzymes and trace elements like; zinc, selenium, glutathione, vitamins $\mathrm{A}, \mathrm{C}$, riboflavin, $\mathrm{D}$, and $\mathrm{E}[6-8]$, as well as increased markers of lipid peroxidation [9] in SCD patients.

The cognitive disabilities in SCD patients include deficits in short-term memory and difficulties in verbal tasks that lead to declining IQ scores and learning difficulties [10]. Few previous studies had evaluated the cognition in relation to oxidative stress in SCD patients, but to our knowledge' none of them evaluated the effects of antioxidant on cognition in children. In this work, we aimed to assess the cognitive impairment in Egyptian children with sickle cell disease and to investigate two antioxidants (vitamin E and selenium) levels and their relationship to IQ values among such group of patients.

\footnotetext{
* Correspondence: niveensab@yahoo.com

${ }^{1}$ Department of Pediatrics, Cairo University, Cairo, Egypt

2Present Address: New Children Hospital, (Abu El Rish), Cairo University

Hospital, Ali Basha Ebrahim, PO Box 11562, Cairo, Egypt

Full list of author information is available at the end of the article
}

\section{Materials and methods}

A case-control study that included fifty-five SCD patients less than 18 years old, who presented to the Hematology Clinic for follow-up. Patients were diagnosed as SCD based on conventional clinical and hematologic criteria. Patients on antioxidant medications and those with known organic brain lesions, autistic spectrum disorder, acute infection or inflammation were excluded from the study. Fifty-five apparently healthy subjects with frequency matched age \& sex were included and served as a control group. Consents were obtained from the patients and their legal guardians before enrollment in the study. The study protocol was approved by the Ethical Committee of Cairo University, according to the 18th World Medical Assembly, Helsinki, Finland. Clinical data and the most recent routine laboratory data were retrieved from medical records as well as patient interviewing. Disease severity was assessed using scoring system for clinical evaluation of SCD patients [11] (Table 1).

Samples were collected and processed according to clinical laboratory specifications, and results were expressed as absolute values as well as percent of patients outside the reference ranges. A blood sample $(10 \mathrm{ml})$ was collected from subjects in the morning after at least $8 \mathrm{~h}$ fasting and all samples from patients were collected just before the transfusion. Blood was transported at room temperature to the analytical laboratory within $20 \mathrm{~min}$ of venipuncture for cell isolation and oxidation analysis. Serum, plasma and cells were separated by centrifugation. Selenium level was assessed using Varian Spectr AA 220 Atomic Absorption Spectrometer equipped with a graphite furnace atomizer and an auto-sampler. Vitamin E assessment has been carried out by Enzyme Linked Immunosorbent Assay (ELISA); which is based on the competitive binding enzyme immunoassay technique and the concentration of Vitamin $E$ in the samples was determined by comparing the optical density of the samples to the standard curve [12].

Assessment of cognitive functions was carried out for all patients and controls using The Stanford-Binet Intelligence Scale, 4th Ed. (SB-IV) [13]; it consists of 15 
Table 1 Scoring system for clinical evaluation of sickle cell patients.11

\begin{tabular}{|c|c|c|c|c|c|}
\hline \multirow[t]{2}{*}{ Clinical Parameters } & \multicolumn{5}{|l|}{ Score } \\
\hline & 1 & 2 & 3 & 4 & 5 \\
\hline $\begin{array}{l}\text { Vaso-occlusive } \\
\text { crisis/year }\end{array}$ & $0-1$ & $>1-3$ & $>3-5$ & $>5-8$ & $>8-12$ \\
\hline $\begin{array}{l}\text { Hospitalization due } \\
\text { to severe vaso-occlusive } \\
\text { crises/year }\end{array}$ & 0 & $1-2$ & $3-4$ & $>5$ & \\
\hline Blood transfusion/year & 0 & $1-2$ & $3-5$ & $>5$ & \\
\hline Acute chest syndrome & No & Yes & & & \\
\hline Stroke & No & Yes & & & \\
\hline $\begin{array}{l}\text { Avascular necrosis } \\
\text { of femur }\end{array}$ & No & Yes & & & \\
\hline Spleen size & Not palpable & $3-4 \mathrm{~cm}$ & $5-7 \mathrm{~cm}$ & & \\
\hline
\end{tabular}

subtests, grouped into four area scores (SB-IV, 1987). SB-IV was used to assess intelligence and cognitive abilities and provides an overall test composite score and standard age scores with an average score of 100 and a standard deviation of 16 .

Statistical analysis: Data were statistically described in terms of mean \pm standard deviation (SD), and range, or frequencies (number of cases) and percentages when appropriate. Comparison of numerical variables between two groups was done by Student's t-test for parametric data or Mann-Whitney U test for non-parametric data. For comparing categorical data, Chi square $\left(\mathrm{X}^{2}\right)$ test was performed. Correlation between various variables was done using Spearman rank correlation coefficient. $P$-value less than 0.05 was considered statistically significant. All statistical calculations were done using SPSS (Statistical Package for the Social Science; SPSS Inc., Chicago, IL, USA) version 15 for Microsoft Windows.

\section{Results}

Normal IQ scores were recorded in 19 SCD patients (34.5\%) while abnormal scores were seen in 36 (65.5\%). Mean IQ of our studied patients was $75.6 \pm 17.4$, with interquartile range (IQR) of $60-85$. While the mean IQ score of the control group was $102.0 \pm 9.5$; the controls had significantly higher IQ scores compared to SCD group $(P=0.01)$. All SCD cases had below normal vitamin $\mathrm{E}$ and Selenium levels; their mean values were significantly lower compared to the control group $(p<0.001)$ (Table 2).

Cases were subdivided into two groups according to their cognitive function; group I with normal cognition and group II with impaired cognition (Table 3).

Impaired cognition was more frequent among females $(p=0.021)$, while both genotypes had similar frequencies $(p>0.05)$. Comparison of clinical and laboratory tests in relation to normal and abnormal IQ is illustrated in (Table 4).
Table 2 Demographic data, antioxidant vitamins and IQ (Stanford Binet) of the study population

\begin{tabular}{|c|c|c|c|c|}
\hline \multicolumn{2}{|l|}{ Variables } & SCD Group $(n=55)$ & Control $(n=55)$ & $P$ value \\
\hline \multicolumn{2}{|c|}{ Age (years) (Mean \pm SD) } & $10.7 \pm 3.1$ & $12.5 \pm 2.4$ & 0.109 \\
\hline \multirow[t]{2}{*}{ Gender $n(\%)$} & Male & $20(36.4 \%)$ & $26(47.3 \%)$ & 0.246 \\
\hline & Female & $35(63.6 \%)$ & $29(52.7 \%)$ & \\
\hline \multicolumn{2}{|c|}{ IQ score (Mean \pm SD) } & $75.6 \pm 17.4$ & $102.0 \pm 9.5$ & $0.01^{*}$ \\
\hline \multicolumn{2}{|c|}{$\begin{array}{l}\text { Vitamin } E(\mathrm{mg} / \mathrm{dl}) \\
(\text { Mean } \pm \mathrm{SD})\end{array}$} & $3.0 \pm 0.6$ & $15.0 \pm 2.5$ & $<0.001^{*}$ \\
\hline \multicolumn{2}{|c|}{$\begin{array}{l}\text { Selenium }(\mu \mathrm{g} / \mathrm{L}) \\
(\text { Mean } \pm \mathrm{SD})\end{array}$} & $27.9 \pm 18.4$ & $110 \pm 7.8$ & $<0.001^{*}$ \\
\hline
\end{tabular}

*Statistically significant, $\mathrm{n}=$ number, $\mathrm{SD}=$ standard deviation, $\mathrm{IQ}=$ intelligence quotient

IQ score correlated inversely with chronological age, age at 1st transfusion, AST and total bilirubin $(\mathrm{r}=-0.424$, $p=0.001 / \mathrm{r}=, p=0.031 / \mathrm{r}=-0.461, p=<0.001 / \mathrm{r}=-0.391$, $p=0.003$ respectively).

\section{Discussion}

Sickle cell disease (SCD) is a genetic disorder caused by a single-point mutation in the 6th position of the hemoglobin beta chain gene, which leads to abnormal hemoglobin, that polymerizes when exposed to low oxygen tension, with subsequent deformity of the erythrocytes which aggregate and cause sluggishness in the microcirculation resulting in local hypoxia, ischemia and tissue damage. SCD complications are frequent; they include bone disease, splenic dysfunction, pulmonary complications, skin ulceration, depression or behavioral disorders, neurologic, and cognitive deficits [4].

Cognitive deficits may include impairment in general cognitive functions as well as deficits in specific areas of cognition including language, short term memory, speed of processing, and working memory [14]. Little information is available on the frequency and risk factors of cognitive impairment in Egyptian children with SCD.

In our study, we assessed the IQ by the Standford Binet test fourth edition [13]. The mean cognitive IQ score among our patients was 75.6 which was significantly

Table 3 Distribution of the studied cases according to the Standford Binet IQ test $(n=55)$

\begin{tabular}{lll}
\hline IQ result & & $\begin{array}{l}\text { Number }(\%) \text { of } \\
\text { cases }(n=55)\end{array}$ \\
\hline $\begin{array}{l}\text { Normal IQ }(n=19): \\
\text { Group I }\end{array}$ & Excellent (IQ: 111-120) & $1(1.8 \%)$ \\
& Average (IQ: 89-110) & $8(14.5 \%)$ \\
& Below average (IQ: 79-88) & $10(18.2 \%)$ \\
Abnormal IQ $(n=36):$ & Slow learner (IQ: 68-78) & $19(34.5 \%)$ \\
Group II & Mild MR (IQ: 52-67) & $13(23.6 \%)$ \\
& Moderate MR (IQ: 36-51) & $4(7.3 \%)$ \\
\hline
\end{tabular}

IQ: intelligence quotient, $\mathrm{MR}=$ mental retardation 
Table 4 Studied clinical and laboratory variables of SCD patients

\begin{tabular}{|c|c|c|c|c|}
\hline \multicolumn{2}{|c|}{ Variable } & Group I $(n=19)$ & Group $\|(n=36$ & $P$ value \\
\hline \multicolumn{2}{|c|}{ Age in years (Mean \pm SD) } & $8.76 \pm 2.40$ & $11.57 \pm 3.36$ & $0.002^{*}$ \\
\hline \multirow[t]{2}{*}{$\operatorname{Sex} n(\%)$} & Male & $11(57.9 \%)$ & $9(25 \%)$ & $0.021^{*}$ \\
\hline & Female & $8(42.1 \%)$ & $27(75 \%)$ & \\
\hline \multirow[t]{2}{*}{ Genotype $n(\%)$} & SS & $12(63.1 \%)$ & $26(72.2 \%)$ & 0.548 \\
\hline & $S \beta$ & 7 (36.9\%) & $10(27.8 \%)$ & \\
\hline \multicolumn{2}{|c|}{ SCD onset (Mean \pm SD) } & $2.71 \pm 2.75$ & $3.87 \pm 3.10$ & 0.087 \\
\hline \multicolumn{2}{|c|}{ Severity score (Mean \pm SD) } & $5.31 \pm 2.08$ & $4.72 \pm 2.53$ & 0.386 \\
\hline \multicolumn{2}{|c|}{$\mathrm{Hb}(\mathrm{mg} / \mathrm{dL})($ Mean $\pm \mathrm{SD})$} & $8.11 \pm 1.61$ & $7.78 \pm 0.99$ & 0.352 \\
\hline \multicolumn{2}{|c|}{ AST (U/L) (Mean \pm SD) } & $38.26 \pm 13.53$ & $48.14 \pm 20.26$ & $0.036^{*}$ \\
\hline \multicolumn{2}{|c|}{ ALT (U/L) (Mean $\pm S D)$} & $23.4 \pm 22.7$ & $28.3 \pm 17.5$ & 0.540 \\
\hline \multicolumn{2}{|c|}{ TSB (mg/dL) (Mean \pm SD) } & $1.27 \pm 0.65$ & $2.82 \pm 3.37$ & $<0.001^{*}$ \\
\hline \multicolumn{2}{|c|}{$\mathrm{DSB}(\mathrm{mg} / \mathrm{dL})($ Mean $\pm \mathrm{SD})$} & $0.24 \pm 0.11$ & $0.44 \pm 0.35$ & $0.001^{*}$ \\
\hline \multicolumn{2}{|c|}{ LDH (U/L) (Mean $\pm S D)$} & $737.47 \pm 462.88$ & $641.15 \pm 429.12$ & 0.447 \\
\hline \multicolumn{2}{|l|}{$\begin{array}{l}\text { Ferritin }(\mathrm{ng} / \mathrm{mL}) \\
(\text { Mean } \pm \mathrm{SD})\end{array}$} & $1037.19 \pm 1081.68$ & $625.83 \pm 751.28$ & 0.089 \\
\hline \multicolumn{2}{|c|}{$\begin{array}{l}\text { Hydroxyurea dose } \\
(\mathrm{mg} / \mathrm{kg} / \mathrm{d})(\text { Mean } \pm \mathrm{SD})\end{array}$} & $17.36 \pm 10.55$ & $13.35 \pm 7.85$ & 0.087 \\
\hline \multicolumn{2}{|c|}{$\begin{array}{l}\text { Hydroxyurea duration } \\
\text { of therapy in years } \\
\text { (Mean } \pm \text { SD) }\end{array}$} & $1.76 \pm 1.84$ & $2.63 \pm 3.06$ & 0.152 \\
\hline \multicolumn{2}{|c|}{$\begin{array}{l}\text { Age at first blood } \\
\text { transfusion (Mean } \pm \text { SD) }\end{array}$} & $1.46 \pm 1.01$ & $2.53 \pm 2.14$ & 0.174 \\
\hline \multicolumn{2}{|c|}{$\begin{array}{l}\text { Frequency of transfusion } \\
\text { per year (Mean } \pm \text { SD) }\end{array}$} & $2.68 \pm 2.71$ & $2.03 \pm 2.93$ & 0.174 \\
\hline \multicolumn{2}{|c|}{$\begin{array}{l}\text { Vitamin } E(\mu \mathrm{g} / \mathrm{mL}) \\
(\text { Mean } \pm \mathrm{SD})\end{array}$} & $3.07 \pm 0.66$ & $3.14 \pm 0.65$ & 0.736 \\
\hline \multicolumn{2}{|c|}{$\begin{array}{l}\text { Selenium }(\mathrm{ng} / \mathrm{mL}) \\
(\text { Mean } \pm \mathrm{SD})\end{array}$} & $27.87 \pm 18.18$ & $27.85 \pm 18.70$ & 0.844 \\
\hline
\end{tabular}

*Statistically significant, $\mathrm{n}=$ number, $\mathrm{SD}=$ standard deviation $\mathrm{SS}=$ homozygous hemoglobin, $S \beta=$ heterozygous sickle beta thalassemia, $\mathrm{Hb}=$ Hemoglobin, $\mathrm{AST}=$ Aspartate aminotransferase, $\mathrm{ALT}=$ Alanine aminotransferase, $\mathrm{TSB}=$ total serum bilirubin, $\mathrm{DSB}=$ direct serum bilirubin, $\mathrm{LDH}=$ Lactate dehydrogenase

lower than that of control (IQ was 102 with $P$ value of 0.01 ). This score was in close approximation to that reported in previous studies $[15,16]$, while Noll et al. reported higher IQ scores in their study where the IQ score reached up to 101.4 [17]. This variation in the reported scores might be related to the presence of silent neurological insults in neurologically free SCD patients; which may affect their intellectual abilities. The frequency of impaired IQ in our studied patients was $65.5 \%$, with most of them categorized as slow learners or having mild mental retardation, these findings were on line with previous reports $[10,18]$.

The cognitive deficits in SCD patients might be multifactorial and the exact risk factors are still not completely clarified. In our studied cases, we found that patients with abnormal IQ were mostly females and were older than those with normal IQ. Age correlated negatively with IQ, which was in agreement with several previous reports stating that IQ decreased with increasing age [10, 19, 20], while contradicted by other studies, which found that age showed no significant difference between SCD patients with normal IQ and those with abnormal score [17, 21]. Moreover, we found that the age of first blood transfusion correlated negatively with the IQ score. A possible explanation is that scheduled blood transfusion early in life improves growth, prevents VOC, limits school absences and hence improves cognition [22].Blood transfusion also increases the total hemoglobin and abates the anemia severity, thus improving the neurocognitive abilities by improving oxygenation and cerebral blood flow [23, 24].

In our studied cases, we found no difference in disease severity between group with abnormal IQ and the group with normal IQ. This has been previously reported [18, 25], however, contradicts have been reported as well, where disease severity was a contributing factor of school absence, leading to poor performance on IQ tests and low verbal abilities [26, 27].

In the current study, the group with abnormal IQ had insignificantly lower hemoglobin than the group with normal IQ. The same findings were detected by other authors $[20,28]$. On the other hand, others found moderate to strong correlation between anemia severity and neurocognitive impairment, where hemoglobin was a strong marker for neurocognitive dysfunction [10, 14, 19, 24, 29].

Other laboratory variables including alanine transaminase (ALT), lactate dehydrogenase (LDH) and serum ferritin showed no significant differences between both groups. A higher total and direct bilirubin were found in patients with abnormal IQ, and negative correlations were found between IQ and both; AST and total bilirubin. These were in agreement with Weiskopf RB and colleague who reported that SCD patients with cognitive impairment had increased bilirubin [30].

In our study, we found no significant association between sickle genotype and IQ score. This was in line with previous studies reporting abnormal IQ equally in all SCD genotypes (Hb-SS, Hb-SC, Hb-SB)0 [31, 32]. A finding that was contradicted by others $[29,33]$ who found that SS genotype patients were more vulnerable to disease related complications, due to lack of fetal hemoglobin which ensures better oxygenation of the brain.

In our studied cases, hydroxyurea dose and duration of therapy were not proved to affect the degree of IQ impairment. Our results mismatch the results of a previous study reporting that neurologically intact SCD children who received regular hydroxyurea scored significantly higher IQ than patients without hydroxyurea [34].

Sickle cell patients are chronically anemic so increase in the cardiac output is required to maintain proper tissue oxygenation; this produces a mildly hyper-catabolic state, increasing resting energy expenditure, and chronic 
oxidative stress [35]. Antioxidant capacity is an important protector against tissue injury, especially in patients with increased oxidant stress. Our patients showed significantly lower levels of the tested antioxidant compared to matching healthy controls. This is in agreement with previous study conducted on Egyptian children [9] while most of the other previous studies concerned with the oxidative stress in chronic hemoglobinopathies were carried out on adults [5-8].

Several authors reported alteration in the lipid soluble vitamins level as vitamin $\mathrm{E}$ in SCD patients [5, 9, 36]. The observed depletion of serum levels of vitamin E can be explained by impairment of liver function due to chronic hepatic iron overload, in addition to increased oxidative processes which cause substantial reduction of serum lipids with a concurrent reduction of serum vitamin $\mathrm{E}[37,38]$.

We observed that SCD patients possess an extremely altered pattern of the tested serum antioxidants namely vitamin E and selenium. All SCD cases had below normal vitamin $\mathrm{E}$ and selenium levels versus none of the control group. This observation is consistent with other authors $[5,9,36,39,40]$, and could be explained by the state of chronic oxidative stress with subsequent depletion of all antioxidants [41]. However, the depleted antioxidants were not proved to be related to IQ scores among the studied population, this could be attributed to the fact that all the patients we studied were deficient in both vitamin $\mathrm{E}$ and selenium.

\section{Limitation}

One of the limitations of our study is that we tested for individual antioxidants like vitamin $\mathrm{E}$ and selenium which may be less informative than other tests like total antioxidant capacity which reflects the collective contribution to the reducing property of non-protein individual antioxidant or electron donating components. Another limiting factor is the lake of magnetic resonance image (MRI) to exclude underling brain disorders that may affect cognition which were not done due to limited financial resources. And lastly the small sample size which might affect our conclusions.

\section{Conclusions and recommendations}

In conclusion, based on the results of this study, cognitive impairment is frequent among SCD children especially females and older patients. SCD patients have depleted antioxidants relative to healthy control, though, we could not detect direct relationship between depleted antioxidants and cognitive functions among such population. Further prospective studies with proper supplementation of vitamin $\mathrm{E}$ and selenium and follow up for changes in the cognitive ability are needed to confirm the role of antioxidant deficiency in cognitive impairment.

\section{Acknowledgments}

We would like to express our sincere thanks and appreciations to our colleagues at the hematology clinic and psychology department of Cairo University children's hospital, for their endless help, support and guidance. We also like to thank all the staff at the department of medical biochemistry, National Research Centre for their effort in analyzing patients' samples and providing us with accurate results. We would like also to thank all the patients with sickle cell disease and their families for their efforts, cooperation and commitment in providing the required data and samples. Thank you so much.

\section{Funding}

This research did not receive any specific grant from funding agencies in the public, commercial, or not-for-profit sectors.

\section{Availability of data and materials}

All data generated and analyzed during this study are available from the corresponding author upon request.

\section{Authors' contributions}

All authors have substantially contributed to the intellectual content of this paper. NS: Conception and design of study, Collection of data, drafting of article and final approval of the version to be published. RF: Shared in putting study design, psychological and cognitive assessment of the studied population, and final approval of the version to be published. ERY: Shared in laboratory work of the study, analysis and interpretation of data and final approval of the version to be published.

\section{Competing interests}

The authors declare that they have no competing interests.

\section{Author details}

${ }^{1}$ Department of Pediatrics, Cairo University, Cairo, Egypt. ${ }^{2}$ Present Address: New Children Hospital, (Abu El Rish), Cairo University Hospital, Ali Basha Ebrahim, PO Box 11562, Cairo, Egypt. ${ }^{3}$ Department of Psychiatry, Cairo University, Cairo, Egypt. ${ }^{4}$ Present Address: Kaser El Einy Hospital, Cairo University Hospital, Cairo, Egypt. ${ }^{5}$ Department of Medical Biochemistry, National Research Center (NRC), Giza, Egypt. ${ }^{6}$ Present Address: 33 EL Bohouth St. (Former EL Tahrir St.), Dokki, Giza, Egypt.

Received: 12 October 2018 Accepted: 15 November 2018

Published online: 14 October 2019

\section{References}

1. Fibach E, Rachmilewitz E (2008) The role of oxidative stress in hemolytic anemia. Curr Mol Med. 8:609-619 https://doi.org/10.2174/ 156652408786241384

2. Aslan M, Ryan TM, Townes TM et al (2003) Nitric oxide-dependent generation of reactive species in sickle cell disease. Actin tyrosine nitration induces defective cytoskeletal polymerization. J Biol Chem. 278:4194-4204

3. Chirico EN, Pialoux V (2012) Role of oxidative stress in the pathogenesis of sickle cell disease. IUBMB Life. 64:72-80 https://doi.org/10.1002/iub.584

4. Swanson ME, Grosse SD, Kulkarni R (2011) Disability among individuals with sickle cell disease, literature review from a public health perspective. Am J Preventive Med 41(6-S 4):S390-S397

5. Walter PB, Fung EB, Killilea DW et al (2006) Oxidative stress and inflammation in ironoverloaded patients with $\beta$-thalassaemia or sickle cell disease. Brit J Haematol. 135 https://doi.org/10.1111/j.1365-2141.2006.06277.x

6. Fasola F, Adedapo K, Anetor J, Kuti M (2007) Total antioxidants status and some hematological values in sickle cell disease, patients in steady state. J Natl Med Assoc. 99:891-894

7. Arinola OG, Olaniyi JA, Akiibinu MO (2008) Evaluation of antioxidant levels and trace element status in nigerian sickle cell disease patients with plasmodium parasitaemia. Pakistan journal of Nutrition. 7:766-769

8. Abiodun ME, Uadia PO, Kuliya GA (2010) Antioxidant enzymes and acute phase proteins correlate with marker of lipid peroxide in adult nigerian sickle cell disease patients. Iran J Basic Med Sci. 13:177-182

9. El-Ghamrawy MK, Hanna WM, Abdel-Salama A, El-Sonbaty MM, Youness ER, Adel A (2014) Oxidant-antioxidant status in Egyptian children with sickle cell anemia: a single center based study. J Pediatria. 90:286-292 
10. Vichinsky EP, Neumayr LD, Gold Jl et al (2010) Neuropsychological dysfunction and neuroimaging abnormalities in neurologically intact adults with sickle cell anemia. JAMA. 303:1823-1831

11. Khushnooma I, Jain D, Gattani S et al (2009) Hydroxyurea in sickle cell disease - a study of clinico-pharmacological efficacy in the Indian haplotype. Blood Cells Mol Dis. 42:25-31 https://doi.org/10.1016/j. bcmd.2008.08.003

12. Rubenstein KE, Schneider RS, Ullman EF (1972) "Homogeneous" enzyme immunoassay. A new immunochemical technique. Biochem Biophys Res Commun. 47:846-851

13. Youngstrom EA, Gluting JJ, Watkins MW (2003) Stanford-binet intelligence scale: Fourth Edition (SB4): evaluating the empirical bases for interpretations 2003. In: Reynolds CR, Kamphaus RW (eds) Handbook of psychological and educational assessment: Intelligence, aptitude, and achievement, vol 2003, 2nd edn, pp 217-242 chapter 10

14. Schatz J, Finke RB, Roberts CW (2004) Interactions of biomedical and environmental risk factors for cognitive development: a preliminary study of sickle cell disease. J Dev Behav Pediatr. 25:303-310

15. Wasserman AL, Wilimas JA, Fairclough DL, Mulhern RK, Wang W (1991) Subtle neuropsychological deficits in children with sickle cell disease. Am J Pediatr Hematol/Oncol. 13:14-20

16. Nabors NA, Freymuth AK (2002) Attention deficits in children with sickle cell disease. Percept Mot Skills. 95:57-67

17. Noll RB, Stith L, Gartstein MA et al (2001) Neuropsychological functioning of youths with sickle cell disease: comparison with non-chronically ill peers. J Pediatr Psychol. 26:69-78 https://doi.org/10.1093/jpepsy/26.2.69

18. Wang W, Enos L, Gallagher D et al (2001) Neuropsychologic performance in school-aged children with sickle cell disease: a report from the Cooperative Study of Sickle Cell Disease. J Pediatr. 139:391-397

19. Hijmans CT, Fijnvandraat K, Grootenhuis MA et al (2010) Neurocognitive deficits in children with sickle cell disease: a comprehensive profile. Pediatr Blood Cancer. 56. https://doi.org/10.1002/pbc.22879

20. King AA, Strouse JJ, Rodeghier MJ et al (2014) Parent education and biologic factors influence on cognition in sickle cell anemia. Am J Hematol. 89:162-167

21. Schatz J, Finke RL, Kellett JM, Kramer JH (2002) Cognitive functioning in children with sickle cell disease: a meta-analysis. J Pediatr Psychol. 27:739748 https://doi.org/10.1093/jpepsy/27.8.739

22. Wang C, Morales KH, Scher CD, Styles L, Olivieri N, Adams R (2005) Effect of long-term transfusion on growth in children with sickle cell anemia: results of the stop trial. J Pediatr. 147:244-247

23. Raj A, Bertolone SJ, Mangold SB, Edmonds HL (2004) Assessment of cerebral tissue oxygenation in patients with sickle cell disease: effect of transfusion therapy. J Pediatr Hematol Oncol. 26:279-283

24. Kral MC, Brown RT, Connelly M et al (2006) Radiographic predictors of neurocognitive functioning in pediatric sickle cell disease. J Child Neurol. 21:37-44

25. Feliu MH, Crawford RD, Edwards L, Wellington C, Wood M, Whitfield E et al (2011) Neurocognitive testing and functioning in adults sickle cell disease. Hemoglobin Int J Hemoglobin Res. 35:476-484 https://doi.org/10.3109/ 03630269.2011 .626098

26. Day S, Chismark E (2006) The cognitive and academic impact of sickle cell disease. J School Nurs. 22:330-335

27. Dyson SM, Atkin K, Culley LA, Dyson SE, Evans H, Rowley DT (2010) Disclosure and sickle cell disorder: a mixed methods study of the young person with sickle cell at school. Soc Sci Med. 70:2036-2044

28. Ruffieux N, Njamnshi AK, Wonkam A, Hauert CA, Chanal J, Verdon V et al (2011) Association between biological markers of sickle cell disease and cognitive functioning amongst Cameroonian children. Child Neuropsychol. https://doi.org/10.1080/09297049.2011.640932. http://www.psypress.com/ childneuropsych. ISSN: 0929-7049print/1744-4136 online

29. Hogan AM, Pit-ten Cate IM, Khadem FV, Prengler M, Kirkham FJ (2006) Physiological correlates of intellectual function in children with sickle cell disease: hypoxaemia, hyperaemia and brain infarction. Dev Sci. 9:379-387

30. Weiskopf RB, Feiner J, Hopf $\mathrm{H}$ et al (2006) Fresh blood and aged stored blood are equally efficacious in immediately reversing anemia-induced brain oxygenation deficits in humans. Anesthesiology. 104:911-920

31. Zafeiriou DI, Prengler M, Gombakis N et al (2004) Central nervous system abnormalities in young patients with S $\beta$ thalassaemia. Ann Neurol. 55:835-839

32. Grueneich R, Ris MD, Ball W et al (2004) Relationship of structural magnetic resonance imaging, magnetic resonance perfusion and other disease factors to neuropsychological outcome in sickle cell disease. Pediatr Psychol. 29:83-92

33. Pegelow CH, Macklin EA, Moser G, Wang WC et al (2002) Longitudinal changes in brain magnetic resonance imaging findings in children with sickle cell disease. Blood. 99:3014-3018

34. Puffer E, Schatz J, Roberts CW (2007) The association of oral hydroxyurea therapy with improved cognitive functioning in sickle cell disease. Child Neuropsychol. 13:142-154

35. Hibbert JM, Creary MS, Gee BE, Buchanan ID, Quarshie A, Hsu LL (2006) Erythropoiesis and myocardial energy requirements contribute to the hypermetabolism of childhood sickle cell anemia. Pediatr Gastroenterol Nutr. 43:680-687

36. Hasanato RMW (2006) Zinc and antioxidant vitamin deficiency in patients with severe sickle cell anemia. Ann Saudi Med. 26:17-21

37. Lubrano R, Frediani T, Citti G et al (1989) Erythrocyte membrane lipid peroxidation before and after vitamin E supplementation in children with cholestasis. J Pediatr. 115:380-384. https://doi.org/10.1016/S00223476(89)80835-2

38. Hamid AA, Aiyelaagbe OO, Usman LA, Ameen OM, Antioxidants LA (2010) Its medicinal and pharmacological applications. Afr J Pure Appl Chem. 4:142-145

39. Zemel BS, Kawchak DA, Fung EB (2002) Effect of zinc supplementation on growth and body composition in children with SCD. Am J Clin Nutr. 75:300-307

40. Ray D, Deshmukh P, Goswami K, Garg N (2007) Antioxidant vitamin levels in sickle cell disorders. Natl Med J India. 20:11-13

41. Claster S, Wood JC, Noetzli L et al (2009) Nutritional deficiencies in iron overloaded patients with hemoglobinopathies. Am J Hematol. 84:344-348

\section{Publisher's Note}

Springer Nature remains neutral with regard to jurisdictional claims in published maps and institutional affiliations.

\section{Submit your manuscript to a SpringerOpen ${ }^{\circ}$ journal and benefit from:}

- Convenient online submission

- Rigorous peer review

- Open access: articles freely available online

- High visibility within the field

- Retaining the copyright to your article

Submit your next manuscript at $>$ springeropen.com 